\title{
Experimental transmission of dermal sarcoma to the sauger Stizostedion canadense
}

\author{
Donald L. Holzschu*, Gregory A. Wooster, Paul R. Bowser** \\ Department of Microbiology and Immunology, College of Veterinary Medicine, Cornell University, Ithaca, New York 14853, USA
}

\begin{abstract}
Walleye dermal sarcoma virus (WDSV) has been identified as the causative agent of a benign neoplasia of walleye Stizostedion vitreum, walleye dermal sarcoma (WDS). We conducted an experimental transmission regimen to determine if WDSV is capable of inducing dermal sarcoma in the closely related sauger $S$. canadense. Nearly all of young-of-the-year saugers (96\%) inoculated with filtrates of spring-collected tumors developed dermal sarcomas, while all of the inoculated walleyes developed tumors. Most of the sauger tumors were limited to the skin, but unvasive tumors, similar to those previously observed in experimental walleyes, were observed in some fish.
\end{abstract}

KEY WORDS: Dermal sarcoma Sauger Neoplasia Retrovirus

\section{INTRODUCTION}

Two species of the percid genus Stizostedion, walleye $S$. vitreum and sauger $S$. canadense, are found in North America (cited in Billington et al. 1991). Allozyme differences and mitochondrial DNA restriction length polymorphisms suggest that walleyes and saugers diverged 3 to 8 million years ago (Billington et al. 1991). Walleyes and saugers are often found in the same bodies of water and are interfertile as are their hybrid off-spring, saugeyes (Stroud 1948, Clayton et al. 1973, Billington et al. 1988, Ward \& Berry 1995). Saugeyes may represent approximately $10 \%$ of the sauger-walleye population in some lakes (Nelson \& Walburg 1977, Van Zee et al. 1996).

Walleye dermal sarcoma (WDS) is a commonly observed benign skin lesion of walleye (Walker 1969, Yamamoto et al. 1976, 1985, Bowser et al. 1988, Martineau et al. 1990). WDS is seasonal, lesions being present from late fall until the spring, when their regression is nearly complete (Bowser et al. 1988, Bowser \&

\footnotetext{
- Present address: Department of Biological Sciences, 108 Irving Hall, Ohio University, Athens, Ohio 45701-2979, USA -.Addressee for correspondence. E-mail: prb4@cornell.edu
}

Wooster 1991). Walleye dermal sarcoma virus (WDSV) has been molecularly cloned from tumor tissue and subsequently shown to be a complex retrovirus (Martineau et al. 1992, Holzschu et al. 1995). WDS has been transmitted experimentally to young-of-the-year (YOY) walleye by intramuscular injection of cell-free filtrates of tumor homogenates (Martineau et al. 1990). While some skin diseases, e.g. lymphocystis, have been documented for walleyes and saugers, there are no published reports of saugers in North America presenting WDS (Amin 1979). In this study, we used our laboratory transmission protocol to establish that infectious WDSV can induce dermal sarcoma in the sauger. The pathology of the lesions is described along with documentation of WDSV presence in the experimentally induced tumors.

\section{METHODS}

Fish. YOY walleye and saugers were obtained from the LaSalle Hatchery of the Illinois Department of Natural Resources, La Salle, IL, USA. Fish were fed swimup fathead minnow fry Pimephales promelas and later frozen guppies Poecilia reticulata, ad libitum during the study. 
Preparation of cell-free inoculum. Cell-free filtrates were prepared from composite samples of WDS collected in the spring of 1996, and from normal walleye skin. The preparation of cell-free filtrates has been described (Bowser et al. 1997). Briefly, tissues collected from adult walleyes were immediately placed on dry ice and stored at $-80^{\circ} \mathrm{C}$. Tumor tissues were thawed, homogenized with a tissue grinder and suspended at a $1: 3$ (weight:volume) dilution in sterile $0.01 \mathrm{M}$ phosphate-buffered saline (PBS; pH 7.2). The suspension was sonicated for $1 \mathrm{~min}$ in the cold at $20 \mathrm{kHz}$ and $28 \mathrm{~W}$ and centrifuged at $1200 \times \mathrm{g}$. The supernatant was passed through a $0.45 \mu \mathrm{m}$ porosity membrane filter to produce the WDS cell-free filtrate for injection. Skin from yearling walleyes was used to prepare a normal skin (control) cell-fiee filtrate by the same procedure employed to prepare tumor filtrates.

Experimental transmission. The fish were kept in $37 \mathrm{l}$ glass aquaria with flowing $15^{\circ} \mathrm{C}$ dechlorinated municipal water and aeration. All fish were acclimated for $1 \mathrm{wk}$ after being stocked in the aquaria. Due to the limited number of fish available, the following study design was used: 28 saugers, in 3 aquaria, were injected with tumor filtrate; 17 saugers, in 2 aquaria, were injected with a normal walleye skin filtrate; 9 walleyes, in 2 aquaria were injected with tumor filtrate while 6 walleyes were injected with the normal skin filtrate. The $14 \mathrm{wk}$ old fish (walleyes, $53 \mathrm{~mm}$ mean total length; saugers, $46 \mathrm{~mm}$ mean total length) were injected with $0.1 \mathrm{ml}$ of cell-free filtrate into the right epaxial musculature. Fish were maintained in the aquaria for $24 \mathrm{wk}$ and observed daily for deaths or adverse signs. At 24 wk post-inoculation, all fish were euthanized with tricaine methane sulfonate (MS-222) and examined grossly for tumors. In an independent experiment reported elsewhere (Bowser et al. 1997), walleyes originating from Oneida Lake, New York, USA, received the same tumor filtrate and control inocula. These fish from New York serve as an additional control to the present study. Fish were fixed in $10 \%$ neutral buffered formalin and 4 cross-sections per fish were embedded in paraffin. Thin sections were stained with hematoxylin and eosin stains for histological examination

Significant differences in percent incidence of tumors between groups of fish were determined with a chi-squared test (STATISTIX for Windows 1.0, Analytical Software, Tallahassee, FL, USA) at the end of the 24 wk study.

PCR amplification of WDSV gag sequences from experimental tumors. During the examination of fish at $24 \mathrm{wk}$, tissue samples from control fish and samples that included tumors along with uninvolved tissue were taken and frozen at $-80^{\circ} \mathrm{C}$. The samples were thawed and added to $1 \mathrm{ml}$ of digestion buffer, $0.5 \%$ sodium dodecyl sulphate (SDS), $100 \mathrm{mM}$ EDTA, $50 \mathrm{mM}$ Tris $\mathrm{pH} 8$, and $500 \mu \mathrm{g} \mathrm{ml} \mathrm{ml}^{-1}$ proteinase K. Following incubation at $55^{\circ} \mathrm{C}$ overnight, $10 \mu \mathrm{g}$ of yeast tRNA (Sigma, St. Louis, MO, USA) was added and the samples were extracted with buffer saturated phenol:chloroform, precipitated with ethanol, and taken up in $100 \mu \mathrm{l}$ of TE $(10 \mathrm{mM}$ Tris $\mathrm{pH} 8.0,1 \mathrm{mM}$ EDTA). One $\mu$ lo of these samples was added to standard polymerase chain reactions (PCR) containing $20 \mathrm{mM}$ Tris- $\mathrm{HCl} \mathrm{pH} \mathrm{8.4,} 50 \mathrm{mM} \mathrm{KCl}, 1.5 \mathrm{mM} \mathrm{MgCl}_{2}, 200 \mu \mathrm{M}$ deoxyribonucleotide triphospate (dNTP), and primers at $0.5 \mu \mathrm{M}$. The mixtures were incubated at $96^{\circ} \mathrm{C}$ for 5 min; 2.5 units of Thermus aquaticus (TAQ) polymerase were added (Gibco BRL, Grand Island, NY, USA), and incubation continued at $94^{\circ} \mathrm{C}$ for $30 \mathrm{~s}, 53^{\circ} \mathrm{C}$ for $30 \mathrm{~s}, 72^{\circ} \mathrm{C}$ for $30 \mathrm{~s}$ for 25 cycles, followed by $72^{\circ} \mathrm{C}$ for $5 \mathrm{~min}$. The forward primer $5^{\prime}$ ATCCCATTGGATTCAGTCTC begins at position 989; the reverse primer 5'GACCGAGTCAGAACTCCGTC begins at position 1495 in the gag gene of the WDSV genome (Holzschu et al. 1995). Amplification products were separated by agarose gel electrophoresis and visualized following staining with ethidium bromide (Sambrook et al. 1989).

\section{RESULTS}

\section{Experimental transmission}

We have used an established WDS transmission protocol to determine if saugers will support dermal sarcoma (Bowser et al. 1990). Survival of the saugers ranged from 82 to $89 \%$; the survival of the Illinois walleyes was lower, $55 \%$ to $66 \%$ (Table 1). Both walleyes and saugers presented dermal sarcoma within weeks of inoculation with dermal sarcoma cell-free filtrates prepared from Oneida Lake, NY, walleyes. Transmission was very efficient, with $96 \%$ and $100 \%$ of the saugers and walleyes presenting tumors, respectively (Table 1). In a parallel experiment using the

Table 1 Stizostedion canadense and S. vitreum. Incidence of walleye dermal sarcoma (WDS) in saugers and walleyes from Illinois injected intramuscularly with cell-free tumor filtrates (WDS) or cell-free filtrates of normal skin (Control). Percentage of fish developing dermal sarcoma in all groups challenged with cell-free tumor filtrate was significantly different from control groups of fish ( $p>0.05 ;$ chi-squared test)

\begin{tabular}{|llcl|}
\hline Fish & Inoculum & $\begin{array}{c}\text { Survival/no. } \\
\text { inoculated }\end{array}$ & $\begin{array}{c}\text { Tumor } \\
\text { positive }\end{array}$ \\
\hline Sauger & WDS & $25 / 28$ & $24 / 25(4 / 24$ invasive) \\
& Control & $14 / 17$ & $0 / 14$ \\
Walleye & WDS & $5 / 9$ & $5 / 5$ \\
& Control & $4 / 6$ & $0 / 6$ \\
\hline
\end{tabular}


same inoculum (Bowser et al. 1997), 100\% of $12 \mathrm{wk}$ old walleyes from New York presented WDS. There were no significant differences $(p>0.05)$ in the incidence of experimentally induced dermal sarcoma between the groups of Illinois saugers, Illinois walleyes and New York walleyes. Most of the saugers presented superficial lesions typical of WDS (Martineau et al. 1990). Four of the saugers presented invasive tumors similar to those seen following injection of $12 \mathrm{wk}$ old walleye fingerlings from New York (Earnest-Koons et al. 1996 Bowser et al. 1997). There was no significant difference $(p>0.05)$ in the incidence of invasive tumors between the saugers $(17 \%)$ and New York walleyes (5\%) (Bowser et al. 1997). The Illinois walleye did not develop invasive tumors, but the small number of fish available for this study does not allow for a meaningful comparison.

Grossly and histologically, the tumors appeared identical to those described previously for WDS (Martineau et al. 1990, Earnest-Koons et al. 1996). The tumors, most numerous near the site of injection, appeared grossly as small (1 to $3 \mathrm{~mm}$ in diameter). slightly raised masses on the surface of the skin. Fig. 1 shows histological examples of the superficial tumors observed on saugers and walleyes. Figs. 2, $3 \& 4$ show sections of invasive tumors of saugers. In Fig. 2 neoplastic cells can be seen that have invaded musculature near the skull. Figs. $3 \& 4$ are of a neoplasm that has invaded and displaced a large portion of the musculature surrounding the vertebral column. Additionally, neoplastic cells have invaded the spinal column causing erosion of the vertebrae.

\section{PCR detection of viral DNA in tumors}

Since WDSV is thought to be the etiological agent of dermal sarcoma, tissue samples were taken at the time af necropsy for DNA preparation and PCR of viral sequences (Fig. 5). A number of nonspecific products
Fig. 1 Stizostedion canadense' and $S$. vitreum. Histological sections of YOY sauger or walleye following intramuscular injections of a cell-free filtrate of walleye dermal sarcoma from an adult walleye. (A) Dermal sarcoma on a young sauger typical of most dermal sarcomas observed during the study, being superficial in nature. LL: lateral line. (B) Dermal sarcoma on a young walleye following intramuscular injection of a cell-free filtrate of walleye dermal sarcoma. Tumor is similar to (A) in its superficial nature
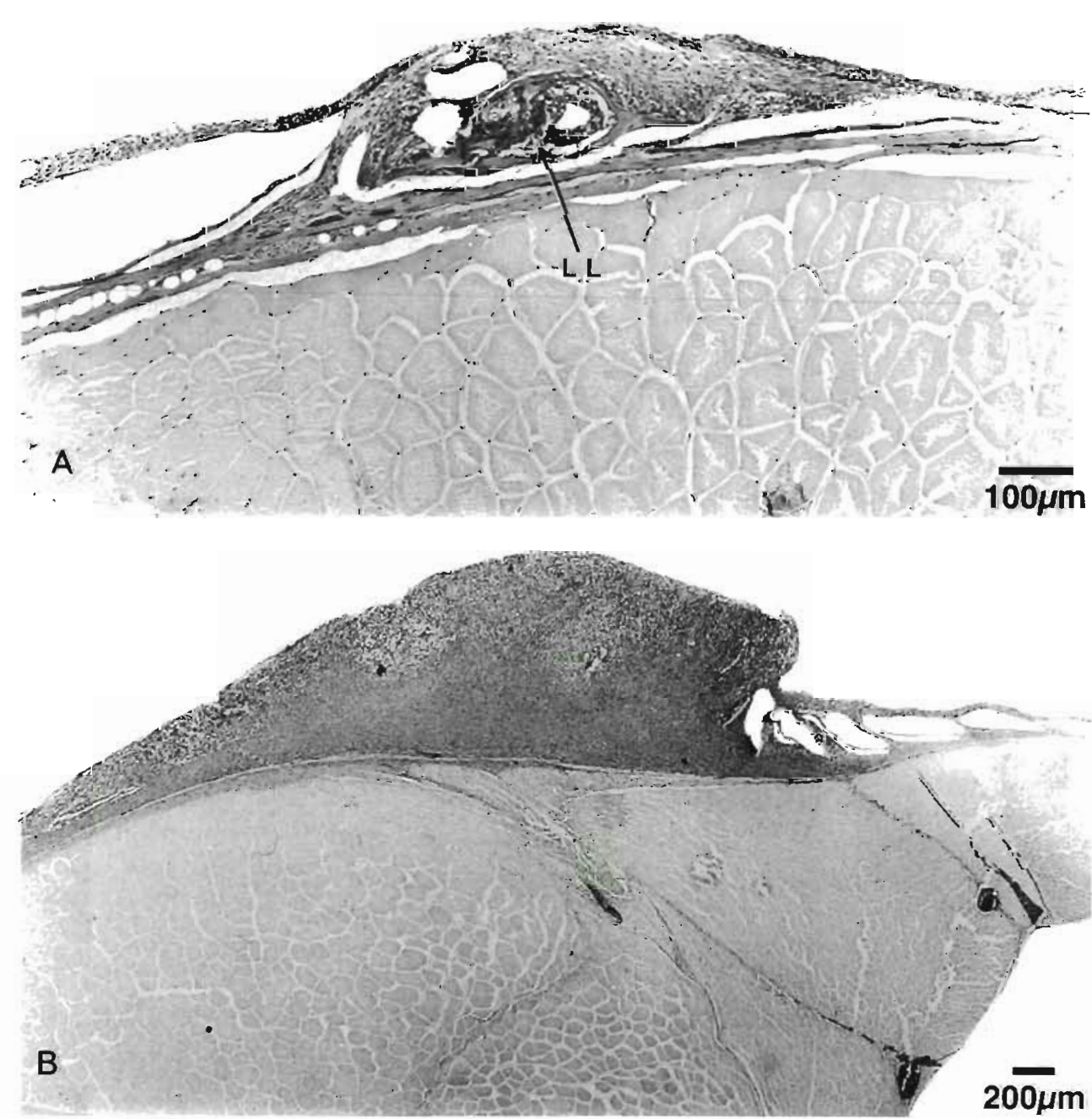


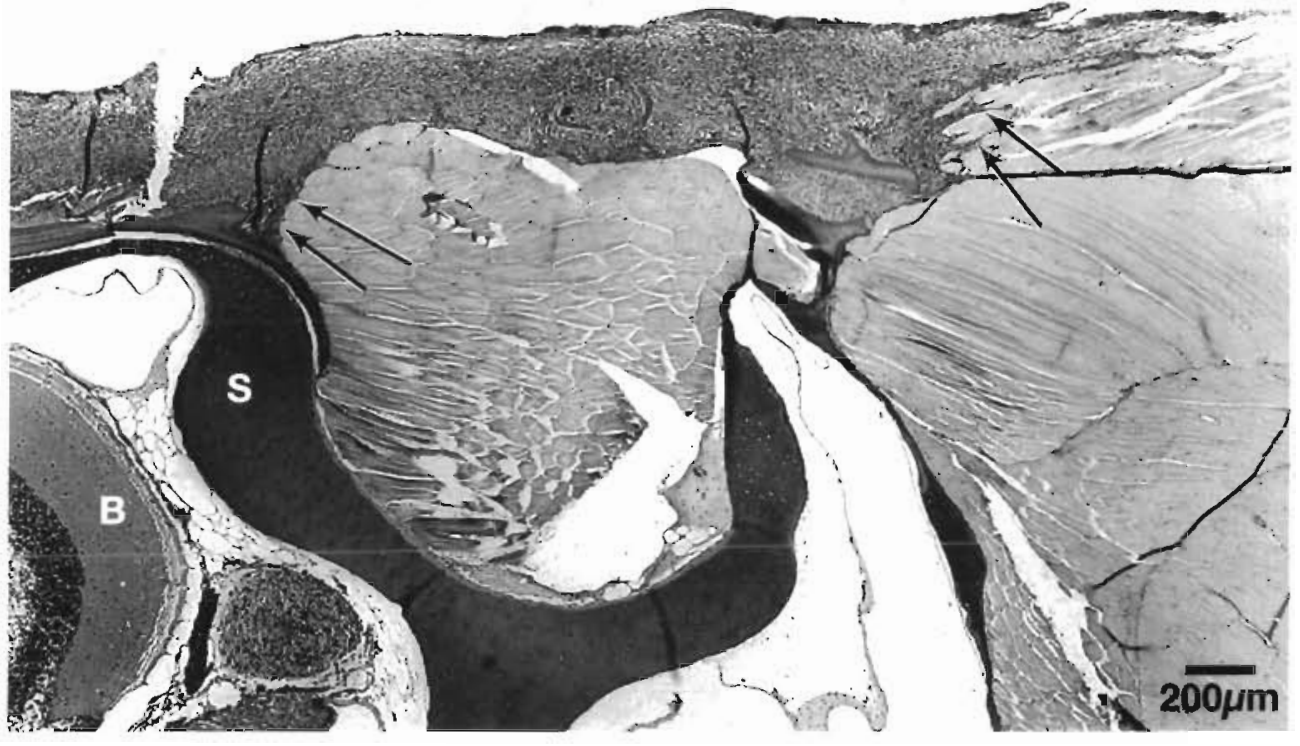

Fig. 2. Stizostedion canadense. Histological section of YOY sauger following intramuscular injection of a cell-free filtrate of walleye dermal sarcoma from an adult walleye. Note the invasive nature of the dermal sarcoma. Neoplastic cells have invaded through the skin into the underlying musculature (arrows) in the region of the skull (S) and brain (B) were amplified by the gag primer pair from both tumorous and control tissues from saugers and walleyes. However, the 495 basepair (bp) viral specific product is only observed in the tumorous tissue samples, lanes 1, 2, and 3 for saugers and lane 7 for wall-

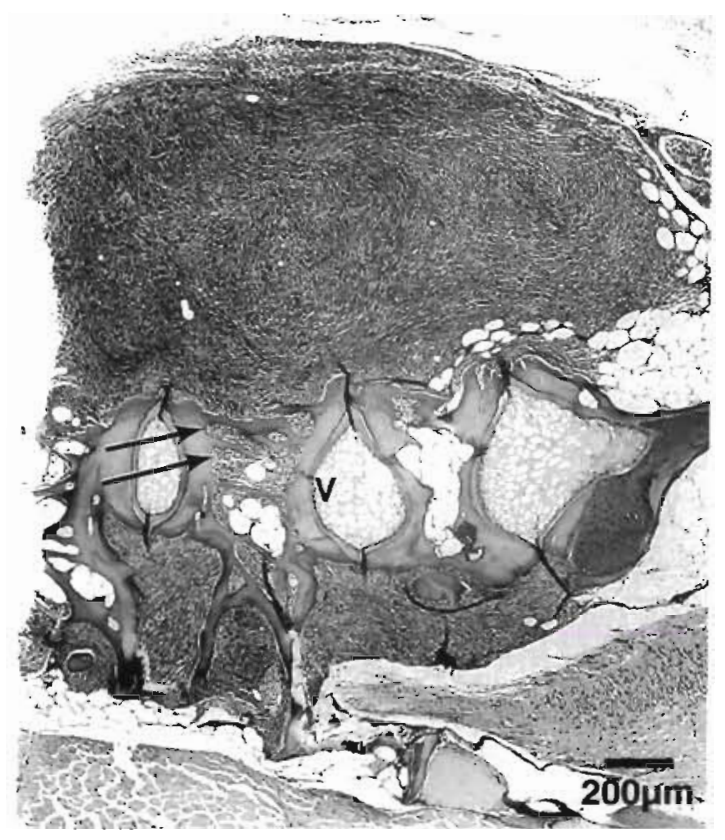

Fig. 3. Stizostedion canadense. Histological section of YOY sauger following intramuscular injection of a cell-free filtrate of walleye dermal sarcoma from an adult walleye. The neoplasm has invaded and replaced much of the musculature surrounding the vertebral column (V). Neoplastic cells have also invaded the spinal column causing an erosion of the bone of the vertebrae (arrows) eye. This band is not present from tissues of control saugers, lanes 4,5 , and 6, or control walleyes, lane 8 . Because many of the tumors were very small and difficult to isolate, most of the tumor samples also contained a large portion of uninvolved tissue. We attribute the weakness of the viral specific bands and the number of nonspecific bands to there being many cells present in the samples that did not harbor viral target DNA. The same phenomenon was observed when using primer pairs derived from the env gene (data not shown).

\section{DISCUSSION}

Walleye and sauger are closely related species that are known to hybridize in nature (Stroud 1948, Clayton et al. 1973, Billington et al. 1988, Ward \& Berry 1995). Approximately $10 \%$ of the fish sampled from 2 Missouri River reservoirs (USA) were identified by morphological traits as F1 walleye-sauger hybrids (Nelson $\&$ Walberg 1977). These results were supported by isozyme analysis of 4 loci that also identified $10 \%$ of the percids from Lewis and Clark Lake in South Dakota, USA, as hybrids (Van Zee et al. 1996). Interestingly, while walleyes and saugers are interfertile and their ranges largely overlap, there are no published reports of saugers presenting a common disease of walleyes, dermal sarcoma. Since there are no reports of saugers that cohabitate water with walleyes presenting dermal sarcoma, it was of interest to determine if the sauger is naturally resistant to dermal sarcoma. 
Fig. 4. Stizostedion canadense. Histological sections of YOY sauger following intramuscular injection of a cell-free filtrate of walleye dermal sarcoma from an adult walleye (high magnification). Note the area of erosion of the spinal column by neoplastic cells (arrows)

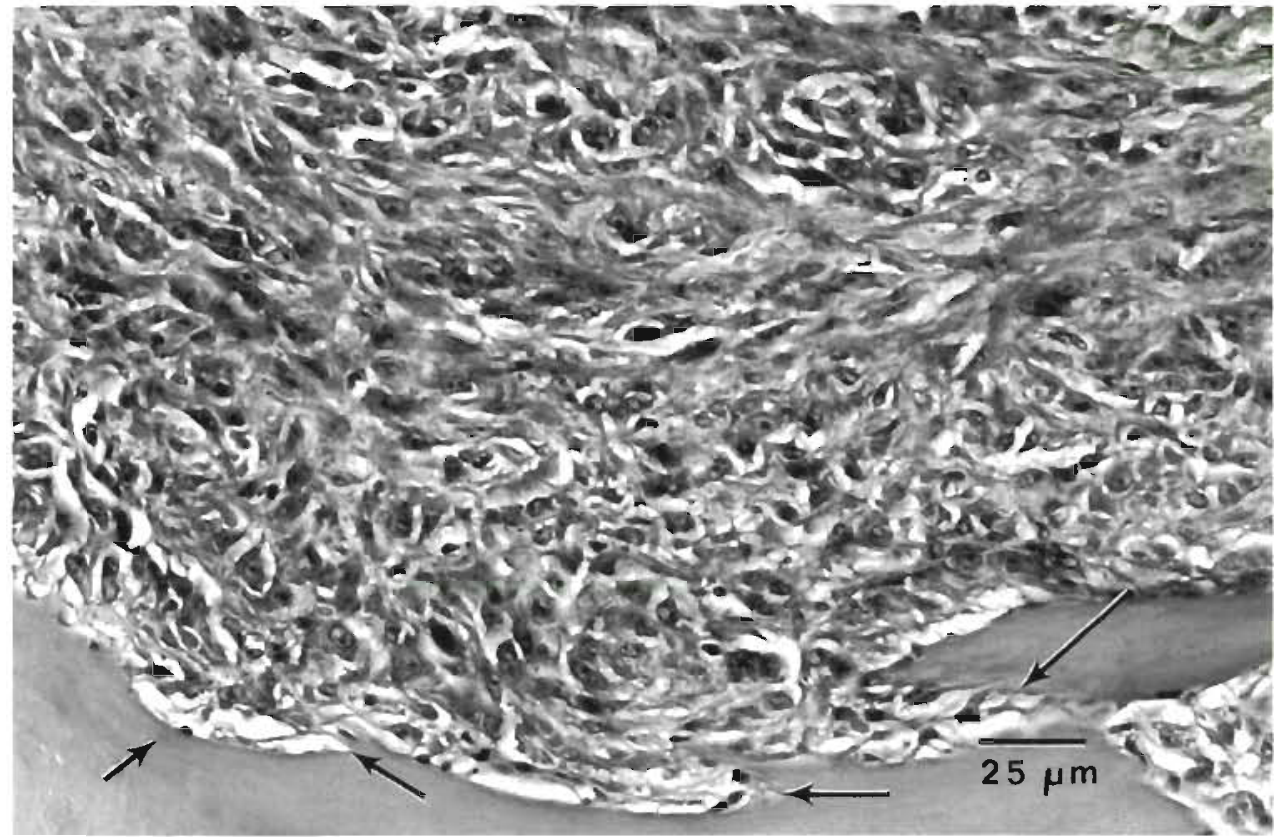

We used an established tumor transmission protocol to investigate the susceptibility of saugers to WDS (Martineau et al. 1990). Our results clearly show that 1 dermal sarcoma can be experimentally transmitted to saugers and that WDSV is present in the lesions. It should be noted, however, that experimental transmission of dermal sarcoma to saugers may not be representative of infection in the wild. We injected the saugers with an inoculum that contains a massive dose of viral particles that may have overwhelmed any resistance the saugers may have to WDSV. Therefore, while we have determined that saugers are susceptible to virally induced dermal sarcoma, further experiments are warranted. Investigations using dilutions of inocula and different routes of transmission need to be made to determine the relatively susceptibility of saugers and walleyes to WDSV induced dermal sarcoma.

Acknowledgements. We thank E. Hanson, Illinois Department of Natural Resources for providing fish used in this study. This work was supported in part by NIH grant RO1CA53623-01A3, USDA/NRI grant 93-03355 and funds from the USDA Animal Health and Disease Program administered by the College of Veterinary Medicine, Cornell University. We also thank Alexis Wenski-Roberts for photomicroscopy support and L. Good, C. Jennings and D. Pasnik for maintaining the fish during this study.

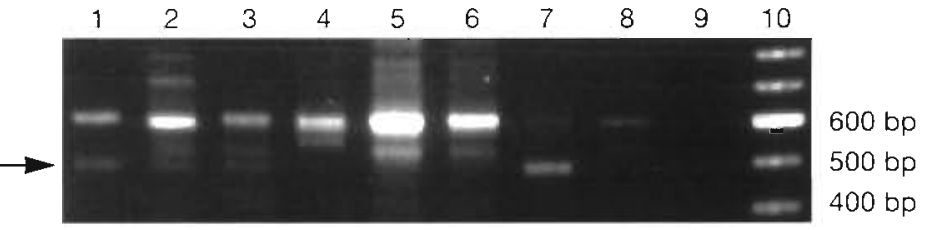

Fig. 5. PCR amplification of a WDSV gag sequence from sauger and walleye tumors. Lanes 1-3: amplification products from dermal sarcomas collected from 3 individual saugers; lanes 4-6: amplification products from 3 uninoculated sauger controls; lane 7: amplification products from a walleye dermal sarcoma; lane 8: amplification products from an uninoculated walleye control; lane 9: no DNA template control; lane 10: 100 basepair ladder (BRL). The arrow points to the gag specific WDSV amplification product. The sizes of the DNA products are shown on the right

\section{LITERATURE CITED}

Amin OM (1979) Lymphocystis disease in Wisconsin fishes J Fish Dis 2:207-217

Billington N, Danzmann RG, Hebert PDN, Ward RD (1991) Phylogenetic relationships among four members of Stizostedion (Percidae) determined by mitochondrial DNA and allozyme analysis. J Fish Biol 39:251-258

Billington N, Hebert PDN, Ward RD (1988) Evidence of introgressive hybridization in the genus Stizostedion: interspecific transfer of mitochondrial DNA between sauger and walleye. Can J Fish Aquat Sci 45:2035-2041

Bowser PR, Martineau D, Wooster GA (1990) Effects of water temperature on experimental transmission of dermal sarcoma in fingerling walleyes (Stizostedion vitreum). $\mathrm{J}$ Aquat Anim Health 2:157-161

Bowser PR, Wolfe MJ, Forney JL, Wooster GA (1988) Seasonal prevalence of skin tumors from walleye (Stizostedion 
vitreum) from Oneida Lake, New York. J Wildl Dis 24 : 292-298

Bowser PR, Wooster GA (1991) Regression of dermal sarcoma in adult walleyes (Stizustedion vitreum). J Aquat Anım Health 3:147-150

Bowser PR, Wooster GA, Earnest-Koons K (1997) Effects of fish age and challenge route in experimental transmission of walleye dermal sarcoma in walleyes by cell-free tumor filtrates. J Aquat Anim Health 9:274-278

Clayton JW, Harris REK, Tretiak DN (1973) Identification of supernatant and mitochondrial isozymes of malate dehydrogenase on electropherograms applied to the taxonomic discrimination of walleye (Stizostedion vitreum vitreum) and sauger (Stizostedion canadense) and suspected interspecific hybrid fishes. J Fish Res Bd Can 30:927-938

Earnest-Koons K, Wooster GA, Bowser PR (1996) Invasive walleye dermal sarcoma in laboratory-maintained walleyes, Stizostedion vitreum. Dis Aquat Org 24:227-232

Holzsrh! DL, Martineau D, Fodor SK, Vogt VM, Bowser PR, Casey JW (1995) Nucleotide sequence and protein analysis of a complex piscine retrovirus, walleye dermal sarcoma virus. J Virol 69:5320-5331

Martineau D, Bowser PR, Armstrong GA, Wooster GA (1990) Experimental transmission of a dermal sarcoma in fingerling walleyes (Stizostedion vitreum vitreum). Vet Pathol $27: 230-234$

Martineau D, Bowser PR, Renshaw RR, Casey JW (1992) Molecular characterization of a unique retrovirus associated with a fish tumor. J Virol 66:596-599

Martineau D, Bowser PR, Wooster GA, Forney JL (1990) Histologic and ultrastructural studies of dermal sarcoma

Editorial responsibility: Nicolaus Peters,

Hamburg, Germany of walleye (Pisces: Stizostedion vitreum). Vet Pathol 27 $340-346$

Nelson WR, Walburg $\mathrm{CH}$ (1977) Population dynamics of yellow perch (Perca flavescens), sauger (Stizostedion canadense), and walleye ( $S$. vitreum vitreum) in four main stem Missouri River reservoirs. J Fish Res Bd Can 34 $1748-1763$

Sambrook J, Fritsch EF, Maniatis T (1989) Molecular cloning a laboratory manual, Cold Spring Harbor Laboratory Press, Cold Spring Harbor, NY

Stroud RH (1948) Notes on growth of hybrids between the sauger and the walleye (Stizostedion canadense $\times S$ vitreum) in Norris Reservoir, Tennessee. Copeia 1948: $297-298$

Van Zee BE, Billington N, Willis DW (1996) Morphological and electrophoretic examination of Stizostedion samples from Lewis and Clark Lake, South Dakota. J Freshwat Ecol 11:339-344

Walke $R$ (1969) Virus assoclated with epidermal hyperplasia in fish. Natl Cancer Inst Monogr 31:195-207

Ward NE III, Berry CR Jr (1995) Evaluation of skin pigmentation for identifying adult saugers and walleye-sauger F1 hybrids collected from Lake Sakakawea, North Dakota. Prog Fish-Cult 57:302-304

Yamamoto T, Kelly RK, Nielson O (1985) Morphological differentiation of virus-associated skin tumors of walleye (Stizostedion vitreum). Fish Pathol 20:361-372

Yamamoto T, MacDonald RD, Gillespie DC, Kelly RK (1976) Viruses associated with lymphocystis disease and dermal sarcoma of walleye (Stizostedion vitreum vitreum). J Fish Res Bd Can 33:2408-2419

Submitted: July 17, 1997; Accepted: November 19, 1997 Proofs received from author(s): February 2, 1998 